\title{
Factors affecting the pheromone composition of voided boar saliva
}

\author{
W. D. Booth \\ AFRC Institute of Animal Physiology and Genetics Research, Cambridge Research Station, \\ Babraham, Cambridge CB2 4AT, U.K.
}

\begin{abstract}
Summary. The pheromone binding protein 'pheromaxein' which binds the pheromonal 16-androstene steroids in the saliva of the male pig (boar), was degraded and lost its binding activity in saliva incubated in air for $72 \mathrm{~h}$ at $21^{\circ} \mathrm{C}$ and $37^{\circ} \mathrm{C}$. However, pheromaxein and its binding activity were retained in saliva incubated for $168 \mathrm{~h}$ at $4^{\circ} \mathrm{C}$. When the ${ }^{3} \mathrm{H}$-labelled pheromones $5 \alpha$-androst-16-en-3 $\alpha$-ol ( $3 \alpha$-androstenol), $5 \alpha$ androst-16-en-3-one ( $5 \alpha$-androstenone) and $5 \alpha$-androst-16-en-3 $\beta$-ol ( $3 \beta$-androstenol) were incubated with boar saliva for $168 \mathrm{~h}$ at $21^{\circ} \mathrm{C}, 3 \alpha$-androstenol was primarily converted to $5 \alpha$-androstenone and $5 \alpha$-androstenone to $3 \beta$-adrostenol; $3 \beta$-androstenol was unchanged. Evidence was obtained for microorganisms being responsible for these steroid transformations.
\end{abstract}

\section{Introduction}

When a mature boar is aroused by the presence of oestrous pigs or unfamiliar boars, he champs copious amounts of frothy saliva. Frequently the saliva foam falls to the ground or is deposited on objects in the environment by a rubbing action of the boar's snout. The purpose of the excessive salivation is to provide a medium for the release of large amounts of musk-smelling 16-androstene steroids into the environment. These odorous steroids, in particular $5 \alpha$-androst-16-en- $3 \alpha$-ol ( $3 \alpha-$ androstenol) and 5 $\alpha$-androst-16-en-3-one ( $5 \alpha$-androstenone), act as signalling pheromones by facilitating the adoption of the mating stance in oestrous pigs (Melrose et al., 1971; Reed et al., 1974; Perry et al., 1980) and probably indicate to other boars that their status is being challenged (Booth \& Baldwin, 1980). There is also evidence suggesting that $3 \alpha$-androstenol has a primer pheromone role in the 'boar effect' on puberty acceleration in female pigs (Kirkwood et al., 1983; Booth, 1984a).

The pheromonal steroids are primarily produced in the boar's testes (Booth, 1982) and transported in the blood to the submaxillary salivary glands where they are concentrated by association with a specific binding protein called 'pheromaxein' (Booth, 1984b); the steroid-protein complex is then secreted into the saliva. It is highly likely that pheromaxein is vital for the transportation of the pheromonal steroids in the aqueous medium of saliva, since these steroids are not only very lipophilic, causing boar taint in the fat of mature boars (Booth, 1982; Bonneau, 1982), but occur in very high concentrations in the submaxillary glands and saliva of these animals (Booth, 1980). Since both the signalling and primer pheromone effects of $3 \alpha$-androstenol, and the signalling pheromone effect of $5 \alpha$-androstenone, are mediated by the free steroid (Melrose et al., 1971; Reed et al., 1974), this suggests that the pheromonal steroids dissociate from their binding protein in voided saliva and become volatile as air-born pheromones. Indeed, preliminary observations on the relative amounts of free and bound pheromone in boar saliva had shown that about $10 \%$ of the pheromones are in the free form in freshly voided saliva at $4{ }^{\circ} \mathrm{C}$, increasing to $30 \%$ at 21 and $37^{\circ} \mathrm{C}$ (W. D. Booth, unpublished).

The question arises as to the stability of the pheromonal steroids and pheromaxein in voided saliva, since changes in the nature of these factors due to decomposition are likely to affect the 
pheromone potency of saliva deposited in the environment. Experiments were therefore carried out to examine some factors which are likely to influence the fate of the pheromonal steroids in voided boar saliva.

\section{Materials and Methods}

Saliva samples. Saliva was collected into beakers as it dripped from the mouths of two aroused domestic boars while they were mounting a dummy to provide semen samples. The saliva was centrifuged to precipitate debris and the supernatants stored frozen at $-70^{\circ} \mathrm{C}$.

The stability of pheromaxein. Saliva was thawed and samples $(0.2 \mathrm{ml})$ were incubated at 4,21 and $37^{\circ} \mathrm{C}$, for 24,72 , and $168 \mathrm{~h}$ at each selected temperature. After each of these times the saliva samples were diluted to $0.5 \mathrm{ml}$ with $10 \mathrm{mmol}$ Tris $-\mathrm{HCl}(\mathrm{pH} 7 \cdot 4) / 1$ containing EDTA $(1 \mathrm{mmol} / 1)$ and $1 \%$ propanediol, and incubated for $1 \mathrm{~h}$ at $4^{\circ} \mathrm{C}$ with 300000 c.p.m. [5a,6a- $\left.{ }^{3} \mathrm{H}\right] 5 \alpha$-androstenone (sp. act. $25 \mathrm{Ci} / \mathrm{mmol}$ : Isocommerz, Dresden, East Germany). The samples were then subjected to non-denaturing polyacrylamide gel electrophoresis (PAGE) using 7\% acrylamide specially purified for electrophoresis (BDH Ltd, Poole, Dorset, U.K.). A detailed account of the method has been described (Booth, 1984b). The distribution of ${ }^{3} \mathrm{H}$-labelled 16-androstene steroid on the gel, and its association with pheromaxein, were determined by scintillation counting of $2 \mathrm{~mm}$ gel slices.

The stability of pheromonal steroids. Saliva $(2-3 \mathrm{ml})$ was filtered through a Millex-GS, non-pyrogenic sterile filter $(0.22 \mu \mathrm{m})$ (Millipore, Harrow, U.K.). Samples $(0.2 \mathrm{ml})$ were taken from the filtrate and also from unfiltered saliva before dilution with $0.3 \mathrm{ml}$ of $10 \mathrm{mmol}$ Tris- $\mathrm{HCl}(\mathrm{pH} 7.4) / 1$ containing EDTA $(1 \mathrm{mmol} / \mathrm{l})$. Some samples received buffer containing $1.2 \mathrm{mg}$ of the antibiotic kanamycin sulphate (Sigma (London) Poole, Dorset, U.K.). The saliva samples and control (buffer only) were then added to loosely screw-capped culture tubes containing 300000 c.p.m. of $\left[{ }^{3} \mathrm{H}\right] 5 \alpha$-androstenone, $\left[{ }^{3} \mathrm{H}\right] 3 \alpha$-androstenol or $\left[{ }^{3} \mathrm{H}\right] 3 \beta$-androstenol (the last two ${ }^{3} \mathrm{H}$-labelled steroids were formed by enzymic reduction of $\left[{ }^{3} \mathrm{H}\right] 5 \alpha$-androstenone as described by Booth (1984b)), and incubated in air for $168 \mathrm{~h}$ at $21^{\circ} \mathrm{C}$. Steroid metabolites and unreacted substrates were extracted with diethyl ether (peroxide free) from May \& Baker (Dagenham, Essex, U.K.) after the addition of carrier steroids, and purified by thin-layer and radio-gas liquid chromatography (see Booth, 1984b).

\section{Results}

\section{Pheromaxein stability}

Figure 1 shows the binding profiles for $\left[{ }^{3} \mathrm{H}\right] 16$-androstene steroid to the two $\alpha$ - and $\beta$-charge isomers of pheromaxein which occurred in the saliva of one boar. Binding of steroid to pheromaxein in saliva incubated at $4^{\circ} \mathrm{C}$ was essentially unchanged after $168 \mathrm{~h}$; only the $\beta$-isomer showed some reduced binding with time. Binding at zero time (not shown) was the same as that after $24 \mathrm{~h}$ at $4^{\circ} \mathrm{C}$. However, the saliva samples incubated at 21 and $37^{\circ} \mathrm{C}$ had lost most binding activity by $72 \mathrm{~h}$, and all by $168 \mathrm{~h}$. Similar binding profiles were obtained for the other boar which had only the $\beta$-isomer. Binding profiles for 16 -androstene steroid in saliva and submaxillary gland tissue preparations of several pigs have indicated that the presence or absence of one or other of the charge isomers of pheromaxein, is genetically determined (Booth, 1984b). Coomassie blue staining of non-denaturing and denaturing SDS gels (Booth, 1984b) showed that the bands corresponding to pheromaxein and other major salivary proteins had disappeared in saliva samples incubated for $168 \mathrm{~h}$ at 21 and $37^{\circ} \mathrm{C}$; this finding was in keeping with the loss of pheromone binding.

\section{Pheromone stability}

The substrate remained unchanged in the incubation with buffer only or filtered saliva. However, in untreated saliva incubations, $\left[{ }^{3} \mathrm{H}\right] 3 \alpha$-androstenol was primarily converted to $\left[{ }^{3} \mathrm{H}\right] 5 \alpha$ androstenone (mean \pm s.d. 2 boars, $29.4 \pm 1.48 \%$ ) with some $\left[{ }^{3} \mathrm{H}\right] 3 \beta$-androstenol (mean \pm s.d. 2 boars, $11.9 \pm 3 \cdot 34 \%$ ). Substrate $\left[{ }^{3} \mathrm{H}\right] 5 \alpha$-androstenone was primarily converted to $\left[{ }^{3} \mathrm{H}\right] 3 \beta$ androstenol (mean \pm s.d. 2 boars, $8.41 \pm 0.70 \%$ ) and $\left[{ }^{3} \mathrm{H}\right] 3 \alpha$ androstenol (mean \pm s.d. 2 boars $1 \cdot 71 \pm 0.8 \%)$; no other metabolites were formed. Substrate $\left[{ }^{3} \mathrm{H}\right] 3 \beta$-androstenol remained unchanged in all incubations. The presence of kanamycin prevented or markedly reduced the metabolism of a particular substrate. The results of incubations with $\left[{ }^{3} \mathrm{H}\right] 3 \alpha$-androstenol are summarized in Fig. 2. 

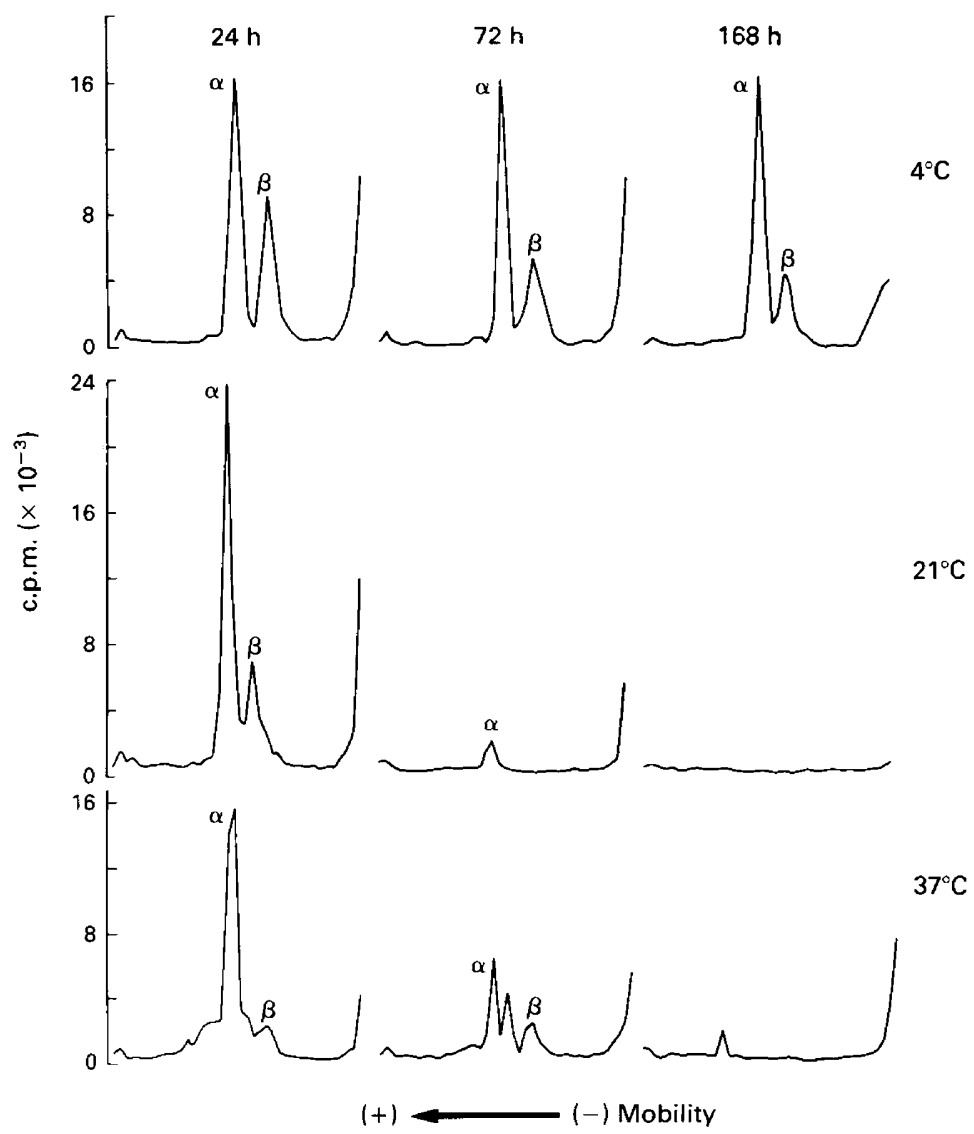

Fig. 1. Non-denaturing polyacrylamide gel $(7 \%)$ electrophoresis of a boar saliva sample incubated with $\left[{ }^{3} \mathrm{H}\right] 5 \alpha$-androstenone for different periods at different temperatures. The binding of the ${ }^{3} \mathrm{H}$-labelled pheromone to its binding protein (pheromaxein existing as $\alpha$ - and $\beta$-charge isomers) was retained for $168 \mathrm{~h}$ at $4^{\circ} \mathrm{C}$, but lost at 21 and $37^{\circ} \mathrm{C}$ due to decomposition of the binding protein.

\section{Discussion}

In the free-ranging pig, particularly the feral animal and wild boar, adult males and females are free to associate with each other at any time of the year, but the greatest degree of contact is during the breeding season. One can speculate that it is at this time when maximum amounts of saliva would be deposited in the environment with the boars being aroused during competitive encounters with each other, and by the presence of females coming into oestrus. The female pigs would therefore be exposed to high concentrations of the pheromonal steroids emanating directly from the saliva foam on the boars lips, and also from a secondary source, i.e. the saliva deposited by the boars into the environment. This 'environmental' source of pheromones might be particularly important to the wild boar since the main breeding season is during the coldest months of the year, i.e. late autumn and winter (Mauget, 1982). The retention of the pheromonal steroids in saliva deposited in the environment at this time of the year would be optimized, as indicated by the present study, with the degradation of pheromaxein being minimum at low temperatures. However as pheromaxein became slowly degraded, this would provide a background of free pheromone over a period of 


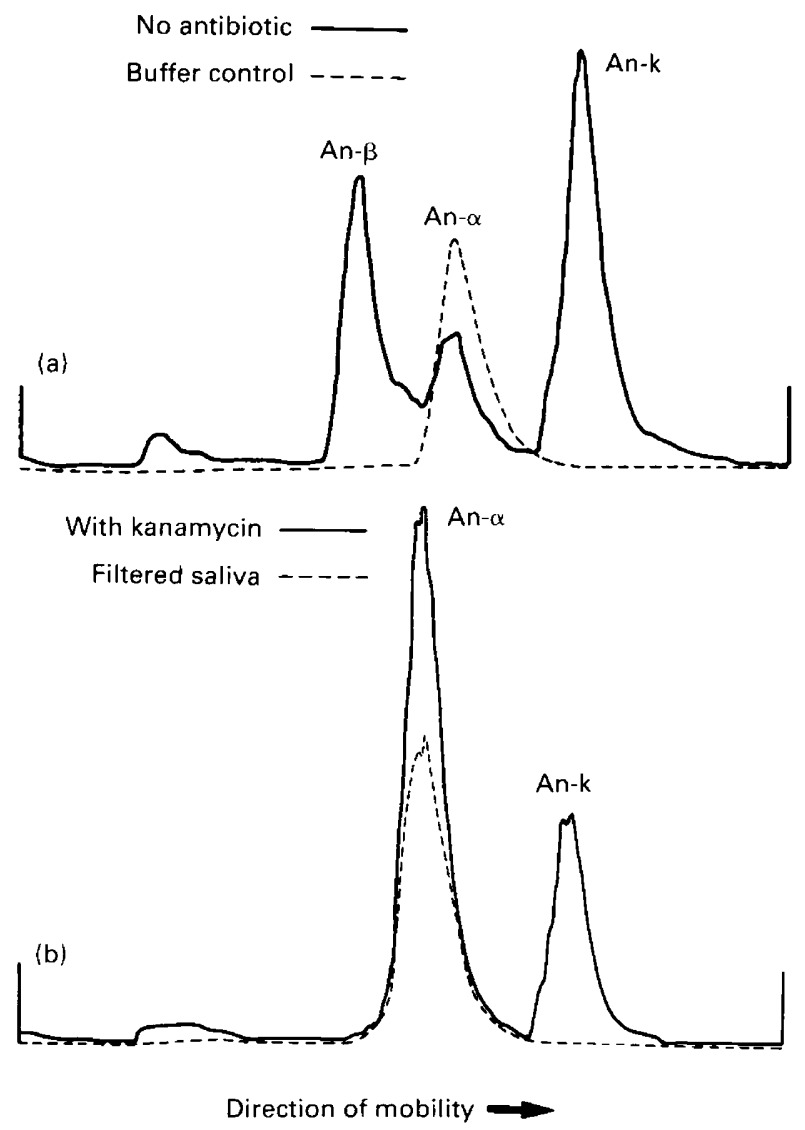

Fig. 2. Thin-layer chromatography (silica gel with solvent systems toluene:ethyl acetate, 9:1 $(\mathrm{v} / \mathrm{v})$, run twice; toluene:diethyl ether, $9: 1(\mathrm{v} / \mathrm{v})$ run once) of diethyl ether extracts of boar saliva samples subjected to various treatments before incubation with $\left[{ }^{3} \mathrm{H}\right] 3 \alpha$-androstenol for $168 \mathrm{~h}$ at $21^{\circ} \mathrm{C}$. (a) Superimposed chromatograms of extracts arising from incubations of $\left[{ }^{3} \mathrm{H}\right] 3 \alpha$ androstenol with buffer only and with untreated saliva, (b) superimposed chromatograms of extracts arising from incubations of $\left[{ }^{3} \mathrm{H}\right] 3 \alpha$-androstenol with boar saliva samples containing

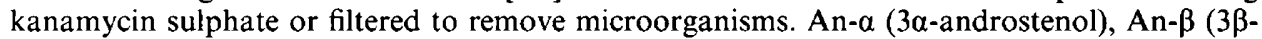
androstenol), An-k (5a-androstenone).

time. In nature this occurrence and the presence of boars would ensure a maximum pheromone stimulus to the female pig whereby oestrus and ovulation are facilitated (Melrose et al., 1971; Reed et al., 1974; Perry et al., 1980; Kirkwood et al., 1983; Booth, 1984a).

The present work has also shown that microorganisms of oral origin in boar saliva are likely to change the relative concentrations of the pheromonal steroids, once the saliva has been deposited in the environment. There is also the strong possibility that the metabolism of the pheromonal steroids would be affected by microorganisms already present in the environment. The results of the present study show that the metabolism of the pheromonal steroids which occurs in voided boar saliva, brought about by salivary microorganisms, proceeds from $3 \alpha$-androstenol and $5 \alpha$-androstenone with known priming and signalling properties, to the relatively inactive $3 \beta$-androstenol (Reed et al., 1974). This pattern of metabolism parallels the sequence of reproductive events in the female pig, i.e. induction of ovarian activity, oestrous behaviour associated with ovulation and then an apparent refractory state to the pheromonal steroids in the postovulatory period. 
Further evidence to support the finding that microorganisms were involved in the metabolism of pheromonal steroids in boar saliva, was obtained from short-term incubations of saliva from the same two boars with $\left[{ }^{3} \mathrm{H}\right] 3 \alpha$-androstenol (W. D. Booth \& S. H. Lambie, unpublished). In these incubations, pheromone metabolism increased with time using saliva which had been frozen and thawed without a cryoprotective agent to preserve the integrity of cells such as leucocytes. It is therefore unlikely that leucocytes were responsible for the steroid metabolism under these circumstances, although it has been demonstrated that these cells are responsible for steroid metabolism in fresh saliva collected from patients with gingivitis (Elattar, 1975). The class of steroid-transforming enzymes detected in boar saliva, i.e. 3-oxidoreductases, is commonly found in microorganisms (Charney \& Herzog, 1967). Although the production of $5 \alpha$-androstenone in human axillary sweat seems to be due to bacteria (Bird \& Gower, 1982), it has yet to be determined which type of microorganism is responsibile for the metabolism of the pheromonal steroids in freshly voided boar saliva.

Preliminary evidence has also been obtained for the metabolism of a number of steroid hormones but excluding cortisol in incubations with boar saliva (W. D. Booth \& S. H. Lambie, unpublished). This finding and those of Elattar (1975) suggest caution in studies in which steroids are measured in saliva as an alternative to blood in animals and man.

I thank Mr Keith Elsome for supervising the boars on the dummy during the collection of saliva.

\section{References}

Bird, S. \& Gower, D.B. (1982) Axillary $5 \alpha$-androst-16-en3-one, cholesterol and squalene in men; preliminary evidence for $5 \alpha$-androst-16-en-3-one being a product of bacterial action. J. Steroid Biochem. 17, 517-522.

Bonneau, M. (1982) Compounds responsible for boar taint with special emphasis on androstenone: a review. Livest. Prod. Sci. 9, 687-705.

Booth, W. D. (1980) Endocrine and exocrine factors in the reproductive behaviour of the pig. Symp. zool. Soc. Lond. 45, 289-311.

Booth, W.D. (1982) Testicular steroids and boar taint. In Control of Pig Reproduction, pp. 25-48. Eds D. J. A. Cole \& G. R. Foxcroft. Butterworths, London.

Booth, W.D. (1984a) A note on the significance of boar salivary pheromones to the male-effect on puberty attainment in gilts. Anim. Prod. 39, 149-152.

Booth, W.D. (1984b) Sexual dimorphism involving steroidal pheromones and their binding protein in the submaxillary salivary gland of the Gottingen miniature pig. J. Endocr. 100, 195-202.

Booth, W.D. \& Baldwin, B.A. (1980) Lack of effect on sexual behaviour or the development of testicular function after removal of olfactory bulbs in prepubertal boars. J. Reprod. Fert. 58, 173-182.

Charney, W. \& Herzog, H.L. (1967) Chemical classification of microbial transformations of steroids. In Microbial Transformations of Steroids pp. 45 and 55. Academic Press, New York.
Elattar, T.M.A. (1975) Metabolism of estrone and progesterone in vitro in human saliva. J. Steroid Biochem. 6, 1455-1458.

Kirkwood, R.N., Hughes, P.E. \& Booth, W.D. (1983) The influence of boar-related odours on puberty attainment in gilts. Anim. Prod. 36, 131-136.

Mauget, R. (1982) Seasonality of reproduction in the wild boar. In Control of Pig Reproduction, pp. 509526. Eds D. J. A. Cole \& G. R. Foxcroft, Butterworths, London.

Melrose, D.R., Reed, H.C.B. \& Patterson, R.L.S. (1971) Androgen steroids associated with boar odour as an aid to the detection of oestrus in pig artificial insemination. Br. vet. $J .127,497-502$.

Perry, G.C., Patterson, R.L.S., MacFie, H.J.H. \& Stinson, C.G. (1980) Pig courtship behaviour: pheromonal property of androstene steroids in male submaxillary secretion. Anim. Prod. 31, 191-199.

Reed, H.C.B., Melrose, D.R. \& Patterson, R.L.S. (1974) Androgen steroids as an aid to the detection of oestrus in pig artificial insemination. Br. vet. J. 130 , 61- 67 . 